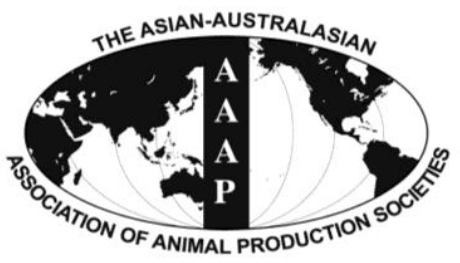

Asian-Aust. J. Anim. Sci.

Vol. 26, No. 4 : 588-595 April 2013

http://dx.doi.org/10.5713/ajas.2012.12488

www.ajas.info

pISSN 1011-2367 elSSN 1976-5517

\title{
Effects of Serial Passage on the Characteristics and Chondrogenic Differentiation of Canine Umbilical Cord Matrix Derived Mesenchymal Stem Cells
}

\author{
K. S. Lee ${ }^{\text {a }}$, S.-H. Cha ${ }^{2, a}$, H. W. Kang, J.-Y. Song, K. W. Lee, K. B. KO ${ }^{2}$ and H. T. Lee ${ }^{1 \text {,* }}$ \\ Viral Disease Division, Animal, Plant and Fisheries Quarantine and Inspection Agency, \\ Anyang 6-dong, Anyang-si, Gyeonggi-do 430-757, Korea
}

\begin{abstract}
Mesenchymal stem cells (MSCs) are often known to have a therapeutic potential in the cell-mediated repair for fatal or incurable diseases. In this study, canine umbilical cord MSCs (cUC-MSCs) were isolated from umbilical cord matrix ( $=3$ ) and subjected to proliferative culture for 5 consecutive passages. The cells at each passage were characterized for multipotent MSC properties such as proliferation kinetics, expression patterns of MSC surface markers and self-renewal associated markers, and chondrogenic differentiation. In results, the proliferation of the cells as determined by the cumulative population doubling level was observed at its peak on passage 3 and stopped after passage 5, whereas cell doubling time dramatically increased after passage 4 . Expression of MSC surface markers (CD44, CD54, CD61, CD80, CD90 and Flk-1), molecule (HMGA2) and pluripotent markers (sox2, nanog) associated with self-renewal was negatively correlated with the number of passages. However, MSC surface marker (CD105) and pluripotent marker (Oct3/4) decreased with increasing the number of subpassage. cUC-MSCs at passage 1 to 5 underwent chondrogenesis under specific culture conditions, but percentage of chondrogenic differentiation decreased with increasing the number of subpassage. Collectively, the present study suggested that sequential subpassage could affect multipotent properties of cUC-MSCs and needs to be addressed before clinical applications. (Key Words: Mesenchymal Stem Cell, Umbilical Cord Matrix, Canine, Multipotent, Differentiation)
\end{abstract}

\section{INTRODUCTION}

A significant number of mesenchymal stem cells (MSCs) are needed for clinical applications which require extensive MSC expansion in culture. However, differentiation potential of bone marrow (BM) and adiposederived MSCs at later passage is often low. In addition, there are several negative reports on MSC senescence (Bonab et al., 2006; Izadpanah et al., 2008; Gruber et al., 2011) or tumor transformation (Rubio et al., 2005; Røsland et al., 2009).

\footnotetext{
* Corresponding Author: H. T. Lee. Tel: +82-2-450-3675, Fax: +82-2-450-3667, E-mail: ht13675@konkuk.ac.kr

1 Department of Animal Biotechnology, Konkuk University, Seoul, Korea, 120 Neungdong-ro, Gwangjin-gu 143-701, Korea.

${ }^{2}$ Research Planning Division, Animal, Plant and Fisheries Quarantine and Inspection Agency, Anyang 6-dong, Anyang-si, Gyeonggi-do 430-757, Korea.

${ }^{a}$ These authors contributed equally to this work.

Submitted Sept. 10, 2012; Accepted Nov. 13, 2012; Revised Dec. 20, 2012
}

Canine derived multipotent MSCs have been established from umbilical cord (Romanov et al., 2003; Secco et al., 2008; Schugar et al., 2009), umbilical cord vein (Zucconi et al., 2010), and umbilical cord blood (Seo et al., 2009). Interestingly, recent research has demonstrated that adipose derived stem cells are capable of long-term self-renewal in culture, while maintaining multipotency in several species, such as human, mouse, canine and bovine (Zuk et al., 2001; Zheng et al., 2006; Neupane et al., 2008; Zhao et al., 2011). However, the presence of a multipotent stem cell population in canine tissues has not yet been fully investigated. Therefore, it is considered important to isolate and characterize canine derived MSCs. For this purpose, we isolated umbilical cord-MSCs (cUC-MSCs) from umbilical cord matrix and subjected to proliferative culture for 5 consecutive passages. The MSCs at each passage were characterized by monitoring the transcriptional patterns of MSC-specific pluripotent and surface markers. Finally, chondrogenic differentiation potentials of cUC-MSCs were also tested. 


\section{MATERIAL AND METHODS}

Isolation of canine umbilical cord matrix (cUCM) cell and cell culture

For this study, whole cUCMs were obtained from three female dogs $(n=3)$ during parturition. The whole cUCMs were first separated from amnion and fetuses. The cUCMs were washed with phosphate buffered saline (PBS) to remove blood. Amniotic epithelium surrounding umbilical cord and blood vessel were dissociated by sterile scissors and forceps, and incubated in $20 \mathrm{ml}$ PBS containing $1 \mathrm{X}$ Pen Strep (penicillin 100 unit $/ \mathrm{ml}$ streptomycin $100 \mu \mathrm{g} / \mathrm{ml}$, GIBCO, USA ) and $0.05 \%$ trypsin/EDTA at $37^{\circ} \mathrm{C}$ for $1 \mathrm{~h}$ to remove remnant amniotic epithelium. Trypsin was inactivated by adding Hank's buffered salt solution supplemented with $10 \%$ fetal bovine serum (FBS). The processed cUCMs were cut into pieces of 1 to $2 \mathrm{~mm}$ size with scissors, and incubated in PBS containing 0.1\% collagenase type I (Sigma) at $37^{\circ} \mathrm{C}$ for $30 \mathrm{~min}$. The digested tissues were passed through cell strainer (BD, USA) (100 $\mu \mathrm{m})$ to remove undigested tissues and centrifuged at 1,500 rpm for $10 \mathrm{~min}$. The cell pellet was resuspended in a growth media, Dulbecco's Modified Eagles Medium (Invitrogen, USA) containing $1 \mathrm{X}$ Pen Strep (penicillin $100 \mathrm{unit} / \mathrm{ml}$ streptomycin $100 \mu \mathrm{g} / \mathrm{ml}$, GIBCO, USA ) and $10 \%$ FBS, and cultured in tissue culture flask at $37^{\circ} \mathrm{C}$ in $5 \% \mathrm{CO}_{2}$ incubator. After $2 \mathrm{~d}$ incubation, cell culture medium was changed with the fresh medium, and cells were passaged every $5 \mathrm{~d}$. Cells at each passage were trypsinized to the single cell and further seeded to contain $5 \times 10^{4}$ per well on a 6-well tissue culture plate and maintained for $5 \mathrm{~d}$ until 80 to $90 \%$ confluence was reached.

\section{Cumulative population doubling level (CPDL)}

During continuous passages, the number of cUC-MSCs at both seeding and harvesting time were counted to calculate CPDL based on the formula " $\mathrm{x}=\left\{\log 10\left(\mathrm{~N}_{\mathrm{H}}\right)\right.$ $\left.\log 10\left(\mathrm{~N}_{\mathrm{I}}\right)\right\} \log 10$ " where $\mathrm{N}_{\mathrm{I}}$ is the initial cell number and $\mathrm{N}_{\mathrm{H}}$ is the harvest cell number. The cumulative doubling level was obtained by adding doubling level of each passage to that of the previous passage (Cristofalo et al., 1998).

\section{Cell doubling time calculation}

Cell doubling times (DT) and numbers (CD) were calculated from hemocytometer counts and cell culture time (CT) for each passage by the formula CD $=\ln \left(\mathrm{N}_{\mathrm{f}} / \mathrm{N}_{\mathrm{i}}\right) \ln 2$ and DT $=C T / C D$ where $\mathrm{N}_{\mathrm{i}}$ is the initial cell number and $\mathrm{N}_{\mathrm{f}}$ is the harvest cell number (Vidal et al., 2006).

Reverse transcriptase-polymerase chain reaction (RTPCR) gene expression analysis

RT-PCR primers for pluripotency (Oct3/4, Nanog,
Sox2), MSC surface markers (CD4, CD8A, CD25, CD33, CD34, CD44, CD54, CD61, CD80, CD105, CD117, Flk-1 and HMGA2) and GAPDH internal control were shown in Table 1. Total RNA was extracted from the cUCM-MSCs using TRIzol (Invitrogen, USA). RNA concentration was measured by absorbance at $260 \mathrm{~nm}$ with a spectrophotometer (Thermo, USA), and cDNA was generated using total RNA $(2 \mu \mathrm{g})$, reverse primers $(10 \mathrm{pmol}$ per each) and Superscript II reverse transcriptase (Invitrogen, USA). For pluripotency marker analysis, target genes were amplified in 35 cycles of $94^{\circ} \mathrm{C}(30 \mathrm{~s}), 55^{\circ} \mathrm{C}$ to $60^{\circ} \mathrm{C}(30 \mathrm{~s}), 72^{\circ} \mathrm{C}(20 \mathrm{~s})$, followed with $72^{\circ} \mathrm{C}$ for $10 \mathrm{~min}$. For MSC CD marker analysis, the target genes were amplified in 35 cycles of $94^{\circ} \mathrm{C}(30 \mathrm{~s}), 57^{\circ} \mathrm{C}$ to $60^{\circ} \mathrm{C}(30 \mathrm{~s})$, $72^{\circ} \mathrm{C}(30 \mathrm{~s})$, followed with $72^{\circ} \mathrm{C}$ for $10 \mathrm{~min}$. For differentiation marker analysis, target genes were amplified in 25 cycles of $94^{\circ} \mathrm{C}(30 \mathrm{~s}), 58^{\circ} \mathrm{C}$ to $64^{\circ} \mathrm{C}(30 \mathrm{~s}), 72^{\circ} \mathrm{C}(30$ s), followed with $72^{\circ} \mathrm{C}$ for $10 \mathrm{~min}$. Each sample was analyzed in triplicate. PCR products were separated on $2 \%$ agarose gel by electrophoresis, stained with Red Safe (iNtRon Biotechnology, Korea), and visualized under UV light. Images were digitally captured with a CCD camera (Gel Doc., USA).

\section{Quantitative real-time PCR}

Primers for differentiation markers (Sox9, Aggrecan precursor, Collagen type 2 alpha (COL2A)) and GAPDH internal control were shown in Table 2. Total RNA was extracted from the differentiated cells and cDNA $(5 \mu \mathrm{l})$ of reverse polymerase transcription was used for PCR analysis. The qRT-PCR analysis was carried out in 96-well plates with using LightCycler 480 SYBR Green I Master kit (Roche Diagnostics, Germany). The following program was used for amplification: predenaturation for $10 \mathrm{~min}$ at $95^{\circ} \mathrm{C}$, followed by 40 cycles of denaturation for $10 \mathrm{~s}$ at $95^{\circ} \mathrm{C}$, annealing for $10 \mathrm{~s}$ at $61^{\circ} \mathrm{C}$, and elongation for $10 \mathrm{~s}$ at $72^{\circ} \mathrm{C}$. Melting curve analysis was performed from $65^{\circ} \mathrm{C}$ to $97^{\circ} \mathrm{C}$ to assess the specificity of the qRT-PCR products. Reference genes (GAPDH) that are stably expressed at $61^{\circ} \mathrm{C}$ were used for quantification. Based on the experiment analysis, we calculated qRT-PCR result by using $\mathrm{Ct}$ value.

\section{In vitro differentiation}

For chondrogenic differentiation, $1.6 \times 10^{7}$ cells in $5 \mu \mathrm{l}$ droplets were cultured to maintain hypoxia condition in the growth media at $37^{\circ} \mathrm{C}$ in 4-well tissue culture plate under the presence of $5 \% \mathrm{CO}_{2}$ and then subjected to chondrogenic differentiation medium containing transforming growth factor beta 3 (TGF- $\beta 3$; PT-3003, PT-4124 Lonza Walkersville, USA) for $21 \mathrm{~d}$. All the differentiation media were changed every 2 to $3 \mathrm{~d}$, and the differentiation was evaluated after $21 \mathrm{~d}$. 
Table 1. Primer sequences used for RT-PCR analyses in this study

\begin{tabular}{|c|c|c|c|}
\hline Markers/gene & Primer sequence (5'-3') & $\begin{array}{l}\text { Amplification } \\
\text { size (bp) }\end{array}$ & Reference \\
\hline \multicolumn{4}{|l|}{ Pluripotency } \\
\hline \multirow[t]{2}{*}{ ОСТ3/4 } & Forward TGACGACAACAAAAATCT & 128 & Vaags et al. \\
\hline & Reverse CAGGCATGTGTTCTCCAG & & \\
\hline \multirow[t]{2}{*}{ NANOG } & Forward CCTGCATCCTTGCCAATGTC & 98 & Vaags et al. \\
\hline & Reverse TCCGGGCTGTCCTGAGTAAG & & \\
\hline \multirow[t]{2}{*}{ SOX 2} & Forward AACCCCAAGATGCACAACTC & 152 & Vaags et al. \\
\hline & Reverse CGGGGCCGGTATTTATAATC & & \\
\hline \multicolumn{4}{|l|}{ MSC makers } \\
\hline \multirow[t]{2}{*}{$\mathrm{CD} 4$} & Forward TGCTCCCAGCGGTCACTCCT & 381 & XM534906 \\
\hline & Reverse GCCCTTGCAGCAGGCGGATA & & \\
\hline \multirow[t]{2}{*}{ CD8A } & Forward GAGGAATGAGCCAGCCGCCC & 303 & NM001002935.2 \\
\hline & Reverse GGAGACACCGGCTTGGACGC & & \\
\hline \multirow[t]{2}{*}{$\mathrm{CD} 25$} & Forward GGCAGCTTATCCCACGTGCCAG & 364 & AB501356.1 \\
\hline & Reverse ATGGGCGGCGTTTGGCTCTG & & \\
\hline \multirow[t]{2}{*}{ CD33 } & Forward TTCGGCACGAGGCCAGGACC & 364 & DR105786.1 \\
\hline & Reverse GCTGGCTCCACAACTGGGTGG & & \\
\hline \multirow[t]{2}{*}{ CD34 } & Forward GCCTGCTCAGTCTGCTGCCC & 255 & Filioli et al. \\
\hline & Reverse TGGTCCCAGGCGTTAGGGTGA & & \\
\hline \multirow[t]{2}{*}{$\mathrm{CD} 44$} & Forward GCCCTGAGCGTGGGCTTTGA & 268 & Filioli et al. \\
\hline & Reverse TCTGGCTGTAGCGGGTGCCA & & \\
\hline \multirow[t]{2}{*}{ CD54 } & Forward TCCGTGGACCCAGCAGAAGC & 468 & XM542075 \\
\hline & Reverse GCGGCACGAGAAGTTGGCGA & & \\
\hline \multirow[t]{2}{*}{ CD61 } & Forward GAGGATTGCGCTGCGGCTCC & 412 & NM001003162.1 \\
\hline & Reverse AAAGCCGCCCTCTGGGGCAT & & \\
\hline \multirow[t]{2}{*}{ CD80 } & Forward GCCTCACCTCTCCTGGTGGGA & 369 & AF257653.1 \\
\hline & Reverse TGGCCATACCTGTACAGTGACCTT & & \\
\hline \multirow[t]{2}{*}{ CD105 } & Forward GGTTCACTGCATCAACATGG & 278 & XM546483.2 \\
\hline & Reverse AAGCTGAAGCGCACATCACC & & \\
\hline \multirow[t]{2}{*}{ CD117 } & Forward CTCAGGGGGTGCGAGGGGAA & 332 & AF099030.1 \\
\hline & Reverse TGTGTCTGTGCATTAGTCTGGCTG & & \\
\hline \multirow[t]{2}{*}{ Flk-I } & Forward CTCCGCACCACATCCGCTGG & 337 & XM539273 \\
\hline & Reverse TCCTGCTCGGTTGGCTGGGT & & \\
\hline \multirow[t]{2}{*}{ HMGA2 } & Forward AGTCCCTCCAAAGCAGCTCAAAAG & 75 & NM003484.1 \\
\hline & Reverse GCCATTTCCTAGGTCTGCCTC & & \\
\hline \multicolumn{4}{|l|}{ Housekeeping } \\
\hline \multirow[t]{2}{*}{ GAPDH } & Forward AGTCAAGGCTGAGAACGGGAAACT & 114 & Vieira et al. \\
\hline & Reverse TCCACAACATACTCAGCACCAGCA & & \\
\hline
\end{tabular}

Table 2. Primer sequences used for quantitative PCR analyses in this study

\begin{tabular}{|c|c|c|c|}
\hline Markers/Gene & Primer sequence $\left(5^{\prime}-3^{\prime}\right)$ & $\begin{array}{l}\text { Amplification } \\
\text { size (bp) }\end{array}$ & Reference \\
\hline \multicolumn{4}{|l|}{ Chondrocytes } \\
\hline COL2A & $\begin{array}{l}\text { Forward ATCGGGCCTGTCTGCTTCTTGTAA } \\
\text { Reverse ACATCAGGTCAGGTCAGCCATTCA }\end{array}$ & 134 & Vieira et al. \\
\hline SOX9 & $\begin{array}{l}\text { Forward ACGACTACACTGACCACCAGAACT } \\
\text { Reverse ATGTAGGTGAAGGTGGAGTAGAGGCT }\end{array}$ & 88 & Vieira et al. \\
\hline Aggrecan & $\begin{array}{l}\text { Forward ACAATGCCCAAGACTACCAGTGGA } \\
\text { Reverse TTCTCGTGCCAGATCATCACCACA }\end{array}$ & 166 & Vieira et al. \\
\hline \multicolumn{4}{|l|}{ Housekeeping } \\
\hline GAPDH & $\begin{array}{l}\text { Forward AGTCAAGGCTGAGAACGGGAAACT } \\
\text { Reverse TCCACAACATACTCAGCACCAGCA }\end{array}$ & 114 & Vieira et al. \\
\hline
\end{tabular}




\section{Cytochemical staining}

The differentiated cells were washed twice with PBS, fixed with $4 \%$ formalin for $10 \mathrm{~min}$ and were subjected to cytochemical staining to confirm the lineage specific markers according to the manufacturer's protocols. Chondrogenic differentiation was confirmed with Alcian blue stain kit (NovaUltra ${ }^{\mathrm{TM}}$, IHC World, USA) by detecting glycosaminoglycan stained in blue color.

\section{Statistical analysis}

Cell doubling time and relative expression of differentiation marker genes were analyzed by one-way analysis of variance test or Student's $t$ test $\left(\mathrm{JMP}^{\circledR}\right.$ 6.0; SAS Institute Inc., Cary NC, USA). The graphs were prepared using SigmaPlot (ver. 8.0) (Systat Software, Inc., Point Richmond, CA, USA).

\section{RESULTS AND DISCUSSION}

\section{Cell growth and proliferation kinetics}

cUC-MSCs were isolated from cUCM and grown in plastic tissue culture flasks. The cells were passaged every 5 $\mathrm{d}$ and counted for the number of cells grown after trypsinization. The cells were adherent to the plastic culture plates, and had fibroblast-like spindle shape, forming highly homogenous monolayer (Figure 1A). During five consecutive passages, CPDL of the cells was linearly increased until fourth passage (P4), but decreased thereafter (Figure 1B). In accordance with the CPDL, doubling time was not significantly increased in passage 2 or $3(4.1 / 4.5 \mathrm{~d})$ and P4 (5.8 d) vs P1 (3.6 d). However, the doubling time was significantly increased in P5 (16.7 d) versus P4 (5.8 d) $(\mathrm{p}<0.05$; Figure 1C).

\section{Expression of pluripotency markers}

Expression of pluripotency markers was tested using RT-PCR (Oct3/4, Nanog and Sox2; Figure 2). Expression of Oct3/4 decreased with increasing the number of subpassage. However, expression of Nanog and Sox 2 was negatively correlated with the number of subpassage.

\section{Immunophenotyping of cUCM-MSCs}

Expression of MSC surface markers such as CD4, CD8A, CD25, CD33, CD34, CD44, CD54, CD61, CD80,

A

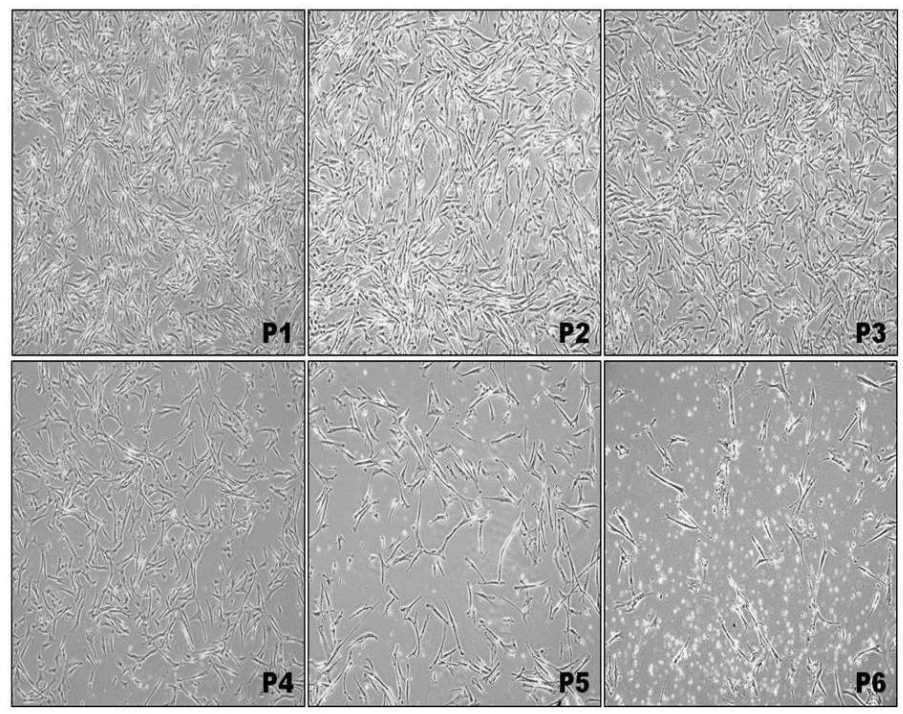

B

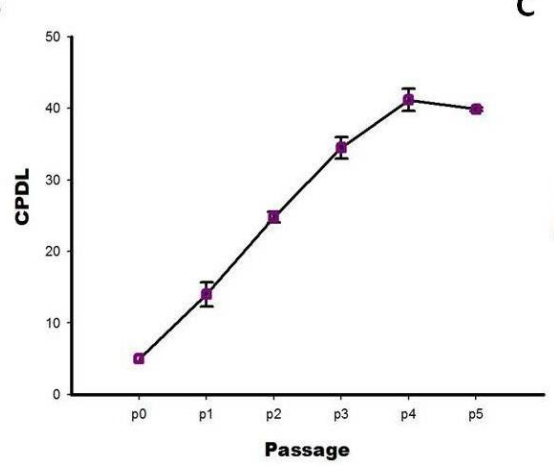

C

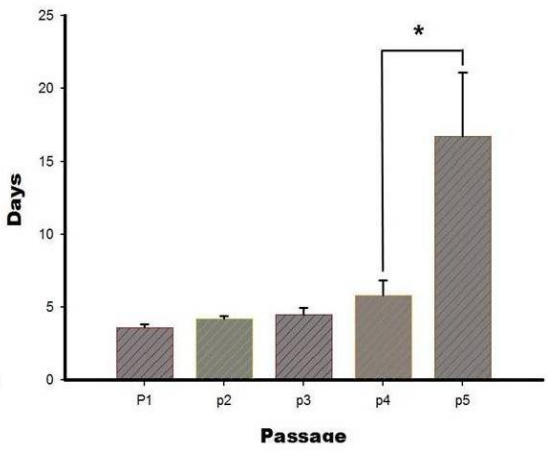

Figure 1. Morphology (P1-P6) (40X) (A) and cumulative population doubling level (B) and doubling time (C) of cUC-MSC during continuous passages. Data are expressed as the mean \pm standard error of values obtained by two determinations. $* \mathrm{p}<0.05$. 


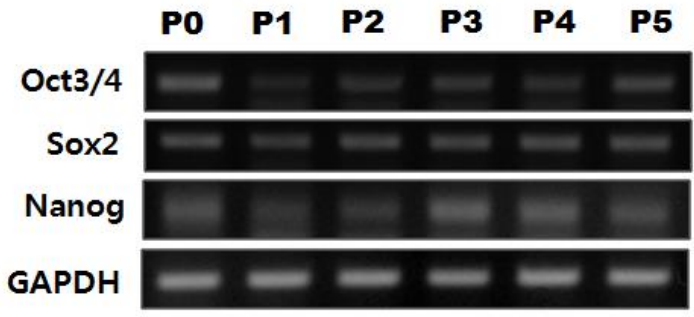

Figure 2. Expression of pluripotency markers (Oct3/4, Nanog and Sox-2) in cUC-MSC during continuous passages by RT-PCR. GAPDH was used as a control. The cells were positive for all markers.

CD90, CD105, CD117, Flk-1and HMGA2 were conducted using RT-PCR. It was shown that cUC-MSCs were positive for CD44, CD54, CD61, CD80, CD90, CD105, Flk-1and HMGA2, but negative for CD4, CD8A, CD25, CD33, CD34 and CD117 (Figure 3). In addition, the expression of CD44, CD54, CD61, CD80, CD90, Flk-1and HMGA2 were negatively correlated with the number of subpassage, but the expression of CD105 decreased with increasing the number of subpassage.

\section{Chondrogenic differentiation}

The cUC-MSCs were cultured for chondrogenic differentiation for $21 \mathrm{~d}$ in specific media. It was apparent that glycosaminoglycans formed in the differentiated cells were stained in blue color by alcian blue (Figure 4A). It was confirmed by alcian blue staining that all cUCM-MSCs from passage 1 and 5 underwent chondrogenic differentiation, but those in early versus late passage displayed more intense glycosaminoglycan staining. Gene expression of markers associated with chondrogenic differentiation such as COL2A (late chondrogenic marker), Aggrecan precursor and Sox9 (early chondrogenic marker) was evident in differentiated cUC-MSCs compared with the undifferentiated cUC-MSCs (Figure 4B). In real-time RTPCR, the dramatic increases in Sox9 and Aggrecan precursor mRNA transcripts were observed in cells from passage 4 and 3 which cultured in chondrogenic medium. However, COL2A mRNA transcripts were significantly decreased with increasing the number of subpassage.

It is well known that MSCs have remarkable potential as a cell-mediate repair and regenerative medicine for fatal or incurable diseases, such as spinal cord injury, arthritis, cartilage regeneration and ischemic heart injury, as demonstrated in the field of stem cell therapy (Pittenger and Martin, 2004; Varma et al., 2007; Hatami et al., 2009; Sharp et al., 2010). In the present study, it was aimed to determine the effects of serial passaging (P1 to P5) on the growth, gene expression of MSC CD markers and chondrogenic differentiation potential of cUCM-MSCs.

There was no significant difference in the population doubling time from P1 to P4 (3.6 to 5.8 d), but P5 cells

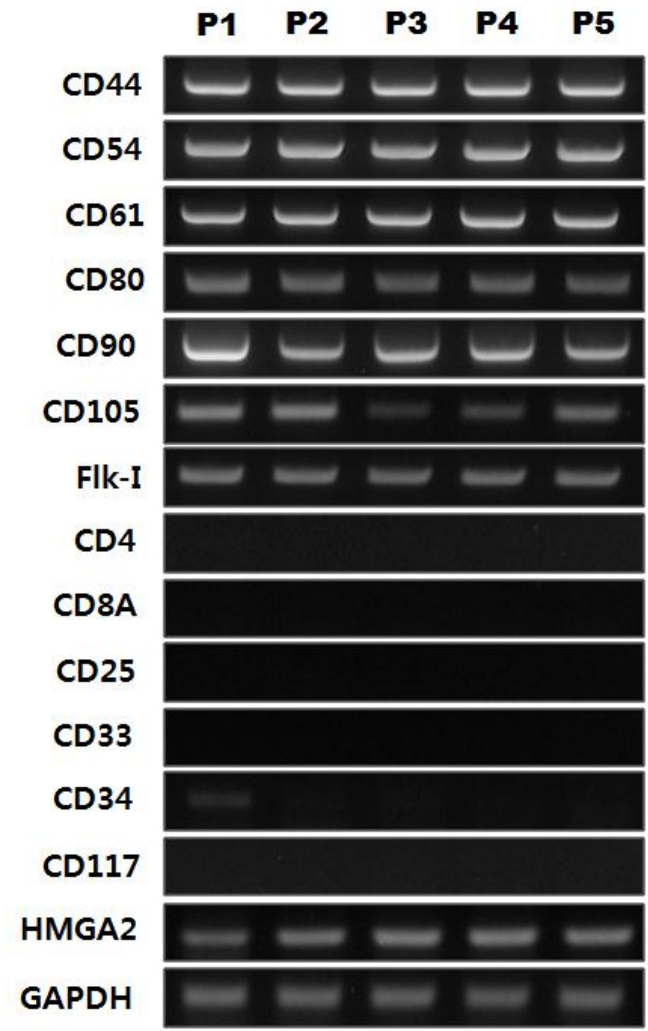

Figure 3. Expression of MSC surface markers in cUC-MSC during continuous passages by RT- PCR. The results indicated that the cUC-MSCs were positive for CD44, CD54, CD61, CD80, CD90, CD105, Flk-1 and HMGA2, while negative for CD4, CD8A, CD25, CD33, CD34 and CD117.

displayed a significantly longer doubling time (16.7 d). This result is consistent with the study by Wall et al. (2007) who found that human ASC doubling times were significantly longer at passage 6 and later. In addition to the slower growth, changes in response to chemical stimuli were observed after passage 4 (Wall et al., 2007). Recent studies reported by Danoviz et al. (2011) and Zhao et al. (2011) showed that increasing doubling times were found in human and bovine adipose stem cells (ASCs) at later passage.

It was found that the cUCM-MSCs expressed pluripotent markers (Oct3/4, Nanog and Sox2) and possessed several surface markers such as CD44, CD54, CD61, CD80, CD90, CD105, Flk-1and HMGA2. However, expression of Oct3/4 was decreased with increasing the number of subpassage. In addition, the expression of Nanog and Sox 2 was negatively correlated with the number of subpassage. It was reported that transcription factors such as Nanog, Rex1, Fzd9, Oct4, Sox2 and Bst1 genes were essential in pluripotency maintenance as well as selfrenewal (Safwani et al., 2012). In study with ASCs, longterm cultures from passage 5 to 15 decreased stemness gene expression levels (Zaman et al., 2008), indicating the negative correlation between the differentiation capability 

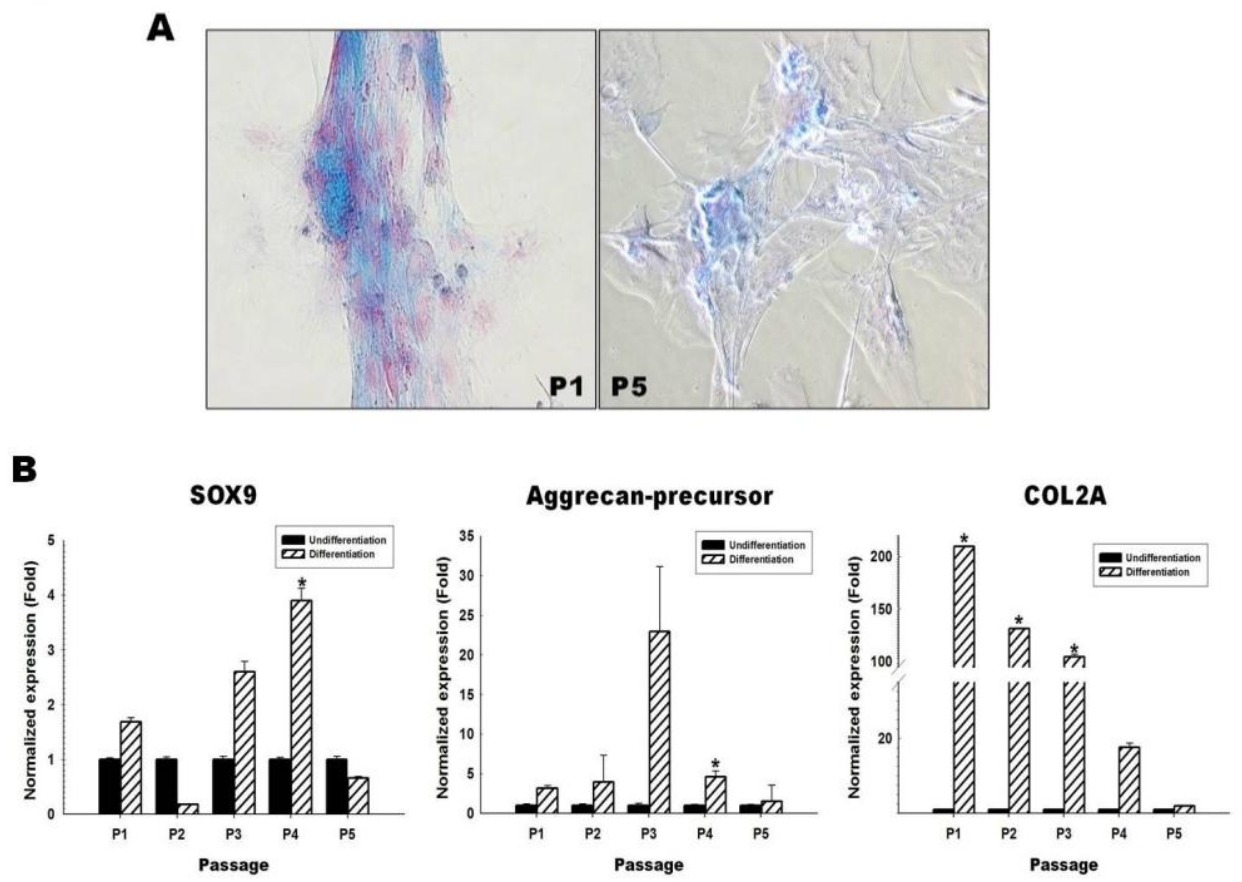

Figure 4. Differentiation potential of cUC-MSC into mesodermal cell lineage, (A) chondrocyte (Alcian blue). The staining was conducted at $21 \mathrm{~d}$ after cells were grown in differentiation media. cUC-MSC showed induction of chondrogenic differentiation. Expression levels of chondrogenic (B) differentiation marker genes were compared between undifferentiated and differentiated cells by Real-time PCR. The expression levels were shown as the mean \pm standard error of the mean $(n=3)$. *: $p<0.0001$ vs undifferented cells.

and serial passage of MSCs as seen in this study. Serial passaging has also been found to alter surface marker expression in human adipose-derived MSCs (Mitchell et al., 2006). Mitchell et al. (2006) demonstrated that the percentage of cells expressing stroma cell markers, including CD105 and CD166 increased with subculture up to passage 4. However, we found that the expression of CD105 was decreased at passage 3 to 5 .

The key role of CD105 in promoting MSC chondrogenesis may be related to its function as a member of TGF- $\beta$ receptor superfamily. CD105 is a dimeric membrane glycoprotein expressed at high levels on human vascular endothelial cells. It shares regions of sequence identity with beta-glycan, a major binding protein for TGF$\beta$, and thus plays an important role in modulating cellular responses to TGF- $\beta$ (Cheifetz et al., 1992; Barry et al., 1999). Since TGF- $\beta$ is the most crucial factor that directs chondrogenesis and chondrogenic differentiation of MSCs (Johnstone et al., 1998; Ito et al., 2002), CD105 expression is probably linked to TGF- $\beta$ mediated chondrogenesis in MSCs.

It is well known that alcian blue staining is a better indicator of the differentiation state of the MSC. In this study the intense of glycosaminoglycan was more pronounced in the early versus late passage MSCs, indicating an enhanced chondrogenesis in the early passage cells.

In addition, gene expression of markers associated with chondrogenic differentiation such as a COL2A, Aggrecan precursor and Sox9 were evident, but the pattern was different between MSCs passages. This observation supports that serial passage also influenced transcriptional levels of differentiation-associated markers in MSCs. Similarly, our gene expression results corroborate with the previous studies that lower expression of Sox9 (Hargus et al., 2008), collagen II and aggrecan were found in the P5induced pellets (Zhao, 2011).

In conclusion, the present study demonstrated that sequential subpassages affect multipotent properties of cUC-MSCs, which should be considered in the trial of therapeutic application of cUC-MSCs.

\section{ACKNOWLEDGEMENTS}

This work was funded by the Animal, Plant and Fisheries Quarantine and Inspection Agency, Ministry for Food, Agriculture, Forestry and Fisheries, the Republic of Korea.

\section{REFERENCES}

Aust, L., B. Devlin, S. J. Foster, Y. D. Halvorsen, K. Hicok, T. du Laney, A. Sen, G. D. Willingmyre and J. M. Gimble. 2004. Yield of human adipose-derived adult stem cells from liposuction aspirates. Cytotherapy 6:7-14.

Barry, F. P., R. E. Boynton, S. Haynesworth, J. M. Murphy and J. Zaia. 1999. The monoclonal antibody $\mathrm{SH}-2$, raised against 
human mesenchymal stem cells, recognizes an epitope on endoglin (CD105). Biochem. Biophys. Res. Commun. 265:134-139.

Bonab, M. M., K. Alimoghaddam, F. Talebian, S. H. Ghaffari, A. Ghavamzadeh and B. Nikbin. 2006. Aging of mesenchymal stem cell in vitro. BMC Cell Biol. 10:7:14.

Cheifetz, S., T. Belloel, C. Cale's, S. Vera, C. Bernabeu, J. Massague and M. Letarte. 1992. Endoglin is a component of the transforming growth factor-beta receptor system in human endothelial cells. J. Biol. Chem. 267:19027-19030.

Cristofalo, V. J., R. G. Allen, R. J. Pignolo, B. G. Martin and J. C. Beck. 1998. Relationship between donor age and the replicative lifespan of human cells in culture: a reevaluation. Proc. Natl. Acad. Sci. 95:10614-10619.

Danoviz, M. E., V. Bassaneze, J. S. Nakamuta, G. R. dos Santosjunior, D. Saint-Clair, M. C. Bajgelman, K. C. Fae, J. Kalil, A. A. Miyakawa and J. E. Krieger. 2011. Adipose tissue-derived stem cell from human and mice differ in proliferative capacity and genome stability in long-term culture. Stem Cells Dev. 20:661-670.

Filioli Uranio, M., L. Valentini, A. Lange-consiglio, M. Caira, A. C. Guaricci, A. L'Abbate, C. R. Catacchio, M. Ventura, F. Cremonesi and M. E. Dell'Aquila. 2011. Isolation, proliferation, cytogenetic, and molecular characterization and in vitro differentiation potency of canine stem cells from foetal adnexa: a comparative study of amniotic fluid, amnion, and umbilical cord matrix. Mol. Reprod. Dev. 78:361-373.

Hargus, G., R. Kist, J. Kramer, D. Gerstel, A. Neitz, G. Scherer and J. Rohwedel. 2008. Loss of Sox9 function results in defective chondrocyte differentiation of mouse embryonic stem cells in vitro. Int. J. Dev. Biol. 52:323-332.

Hatami, M., N. Z. Mehrjardi, S. Kiani, K. Hemmesi, H. Azizi, A. Shahverdi and H. Baharvand, 2009. Human embryonic stem cell-derived neural precursor transplants in collagen scaffolds promote recovery in injured rat spinal cord. Cytotherapy 11:618-630.

Ito, Y., Jr. P. Bringas, A. Mogharei, J. Zhao, C. Deng and Y. Chai. 2002. Receptor-regulated and inhibitory Smads are critical in regulating transforming growth factor betamediated Meckeldi cartilage development. Dev. Dyn. 224:69-78.

Izadpanah, R., D. Kausha, C. Kriedt, F. Tsien, B. Patel, J. Dufour and B. A. Bunnell. 2008. Long-term in vitro expansion alters the biology of adult mesenchymal stem cells. Cancer Res. 68:4229-4238.

Johnstone, B., T. M. Hering, A. I. Caplan, V. M. Goldberg and J. U. Yoo. 1998. In vitro chondrogenesis of bone marrow-derived mesenchymal progenitor cells. Exp. Cell Res. 238:265-272.

Neupane, M., C. C. Chang, M. Kiupel and V. Yuzbasiyan- Gurkan. 2008. Isolation and characterization of canine adipose-derived mesenchymal stem cells. Tissue Eng. Part A. 14:1007-1015.

Mitchell, J. B., K. McIntosh, S. Zvonic, S. Garrett, Z. E. Floyd, A. Kloster, Y. Di Halvorsen, R. W. Storms, B. Goh, G. Kilroy, X. $\mathrm{Wu}$ and J. M. Gimble. 2006. Immunophenotype of human adipose-derived cells: temporal changes in stromal associated and stem cell-associated markers. Stem Cells 24:376-385.

Pittenger, M. F. and B. J. Martin. 2004. Mesenchymal stem cells and their potential as cardiac therapeutics. Circ. Res. 95:9-20.

Romanov, Y. A., V. A. Svintsitskaya and V. N. Smirnov. 2003. Searching for alternative sources of postnatal human mesenchymal stem cells: candidate MSC-like cells from umbilical cord. Stem Cells 21:105-110.

Røsland, G. V., A. Svendsen, A. Torsvik, E. Sobala, E. McCormack, H. Immervoll, J. Mysliwietz, J. C. Tonn, R. Goldbrunner, P. E .Lønning, R. Bjerkvig and C. Schichor, 2009. Long-term cultures of bone marrow-derived human mesenchymal stem cells frequently undergo spontaneous malignant transformation. Cancer Res. 69:5331-5339.

Rubio, D., J. Garcia-Castro, M. C. Martin, R. de la Fuente, J. C. Cigudosa, A. C. Lloyd and A. Bernad. 2005. Spontaneous human adult stem cell transformation. Cancer Res. 65:30353039.

Safwani, W. K., S. Makpol, S. Santhapan, K. H. Chua. 2012. Alteration of gene expression level during osteogenic induction of human adipose derived stem cells in long term culture. Cell Tissue Bank. DOI:10.1007/s10561-012-9309-1.

Schugar, R. C., S. M. Chirieleison, K. E. Wescoe, B. T. Schmidt, Y. Askew, J. J. Nance, J. M. Evron, B. Peault and B. M. Deasy. 2009. High harvest yield, high expansion, and phenotype stability of CD146 mesenchymal stromal cells from whole primitive human umbilical cord tissue. J. Biomed. Biotechnol. doi:10.1155/789526.

Secco, M., E. Zucconi, N. M. Vieira, L. L. Fogaca, A. Cerqueira, M. D. Carvalho, T. Jazedje, O. K. Okamoto, A. R. Muotri and M. Zatz. 2008. Multipotent stem cells from umbilical cord: cord is richer than blood. Stem Cells 26:146-150.

Seo, M. S., Y. H. Jeong, J. R. Park, S. B. Park, K. H. Rho, H. S. Kim, K. R. Yu, S. H. Lee, J. W. Jung, Y. S. Lee and K. S. Kang. 2009. Isolation and characterization of canine umbilical cord blood-derived mesenchymal stem cells. J. Vet. Sci. 10:181-187.

Sharp, J., J. Frame, M. Siegenthaler, G. Nistor and H. S. Keirstead. 2010. Human embryonic stem cell-derived oligodendrocyte progenitor cell transplants improve recovery after cervical spinal cord injury. Stem Cells 28:152-163.

Vaags, A. K., S. Rosic-Kablar, C. J. Gartley, Y. Z. Zheng, A. Chesney, D. A. Villagómez, S. A. Kruth and M. R. Hough. 2009. Derivation and characterization of canine embryonic stem cell lines with in vitro and in vivo differentiation potential. Stem Cells 27:329-340.

Varma, M. J., R. G. Breuls, T. E. Schouten, W. J. Jurgens, H. J. Bontkes, G. J. Schuurhuis, S. M. van Ham and F. J. van Milligen. 2007. Phenotypical and functional characterization of freshly isolated adipose tissue-derived stem cells. Stem Cells Dev. 16:91-104.

Vidal, M. A., G. E. Kilory, J. R. Johson, M. J. Lopez, R. M. Moore and J. M. Gimble. 2006. Cell growth characteristics and differentiation frequency of adherent equine bone marrowderived mesenchymal stromal cells: adipogenic and osteogenic capacity. Vet. Surg. 35:601-610.

Vieira, N. M., V. Brandalise, E. Zucconi, M. Secco, B. E. Strauss and M. Zatz. 2010. Isolation, characterization, and differentiation potential of canine adipose-derived stem cells. Cell Transplant. 19:279-289.

Wall., M. E., S. H. Bernacki and E. G. Loboa. 2007. Effects of serial passaging on the adipogenic and osteogenic differentiation potential of adipose-derived human mesenchymal stem cells. Tissue Eng. 13:1291-1298.

Zaman, W. S., S. Makpol, S. Santhapan and K. H. Chua. 2008. Stemness gene expression profile of human adipose derived 
stem cells in long term culture. Med. J. Malaysia 63:61-62.

Zhao, Y., S. D. Waldman and L. E. Flynn. 2011. The effect of serial passaging on the proliferation and differentiation of bovine adipose-derived stem cells. Cells Tissues Organs 195:414-427.

Zheng, B., B. Cao, G. Li and J. Huard. 2006. Mouse adipose derived stem cells undergo multilineage differentiation in vitro but primarily osteogenic and chondrogenic differentiation in vivo. Tissue Eng. 12:1891-1901.
Zucconi, E., N. M. Vieira, D. F. Bueno, M. Secco, T. Jazedje, C. E. Ambrosio, M. R. Passos-Bueno, M. A. Miglino and M. Zatz. 2010. Mesenchymal stem cells derived from canine umbilical cord vein-A novel source for cell therapy studies. Stem Cells Dev. 19:395-402.

Zuk, P. A., M. Zhu, H. Mizuno, J. Huang, J. W. Futrell, A. J. Katz, P. Benhaim, H. P. Lorenz and M. H. Hedrick. 2001. Multilineage cells from human adipose tissue: implications for cell-based therapies. Tissue Eng. 7:211-228. 